\title{
The Relationship Between Health Literacy Level of Pregnant Women and COVID 19 Knowledge, Attitudes and Behaviors
}

\author{
Gebe Kadınların Sağlık Okuryazarlığı Düzeyinin COVID 19 Bilgi, \\ Tutum ve Davranışlarıyla İlişkisi \\ Mehmet Doğan', Fatma Özdemir² \\ ${ }^{1}$ Erciyes Üniversitesi Halil Bayraktar Sağlık Hizmetleri Meslek Yüksekokulu,Kayseri,Türkiye \\ ${ }^{2}$ Erciyes Üniversitesi Tip Fakültesi Kadın Doğum ve Hastalıkları, Kayseri, Türkiye \\ Yazışma Adresi / Correspondence: \\ Mehmet Doğan \\ Erciyes Üniversitesi Halil Bayraktar Sağlık Hizmetleri Meslek Yüksekokulu /KAYSERİ \\ T: + 903522076666 / Dahili: $40014 \quad$ E-mail : mehmetdogan@erciyes.edu.tr \\ Geliş Tarihi / Received : 15.03 2021 Kabul Tarihi / Accepte: 22.08.2021 \\ Orcid : \\ Mehmet Doğan https://orcid.org/0000-0002-2971-7246 \\ Fatma Özdemir https://orcid.org/0000-0003-1626-3609 \\ ( Sakarya Tip Dergisi / Sakarya Med J 2021, 11(3):533-541) DOI: 10.31832/smj.897489
}

\begin{abstract}
Öz
Objective This study was conducted to determine pregnant women's health literacy level and evaluate the relationship between the determined health literacy levels with COVID 19 knowledge, attitudes, and behaviors.

Materials This descriptive and cross-sectional study was conducted on 381 pregnant women between September 2020 and February 2021. The questionnaire, 25 questions about and Methods socio-demographic characteristics and knowledge, attitudes and behaviors with COVID 19, and "Turkey Health Literacy Scale-32 (THLS-32)" consisting of 32 questions was applied by face-to-face interview technique.

Results The average age of participants is $28.70 \pm 5.45$, and $58.8 \%$ of them have an education level above high school. It is the first pregnancy of $27.0 \%$ of participants. The average week of gestation is $22.45 \pm 9.94$. Of the participants, $23.9 \%$ have inadequate, $19.7 \%$ limited, $28.3 \%$ adequate and $28.1 \%$ have excellent general health literacy. The average general health literacy average is $33.28 \pm 12.63$. Health literacy level is high in participants with education level, employment, number of pregnancies and lower pregnancy $(\mathrm{p}<0.05)$. Adequate health literacy level is higher in participants who say fever, respiratory distress, and cough are the symptoms of COVID-19 ( $p<0.05)$. Adequate health literacy (disease prevention and health promotion) level is higher in participants who avoid close contacts such as handshaking or hugging $(\mathrm{p}<0.05)$.

Conclusion More than half of pregnant women is adequate health literacy levels. Adequate health literacy is high in compliance COVID-19 rules. Improving health literacy can provide benefits in solving both COVID-19 disease and other health problems.

Keywords Health Literacy; Pregnant; COVID-19; Behavior
\end{abstract}

Amaç Bu çalıșma gebe kadınların sağllk okuryazarlı düzeyini belirlemek ve belirlenen sağllk okuryazarlık düzeylerinin COVID 19 bilgi, tutum ve davranışlarıla Ilişkisini değerlendirmek amactyla yapılmıștır.

Gereç ve Tanımlayıcı ve kesitsel nitelikteki bu çalșma Eylül 2020 - Şubat 2021 tarihleri arasında 381 gebe kadın üzerinde uygulanmıştır. 25 sorudan oluşan sosyo-demografik özellikler ve COVID 19

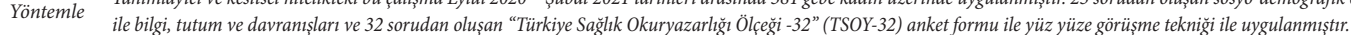

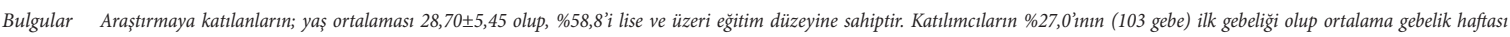

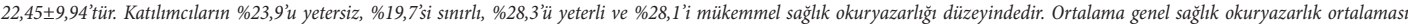
$33.28 \pm 12.63$ 'dür. Eğitim düzeyi, calısma, gebelik sayıst ve düsü̈̆̈̈ olanlarda yeterli sağllk okuryazarllk düzeyi yüksektir $(p<0,05)$. COVID-19’un semptomları olarak ates, solunum sıkintısı ve öksürük olduğınu söyleyenlerde yeterli sağllk okuryazarlk düzeyi daha yüksektir $(p<0,05)$. Tokalaşma, sarılma gibi yakın temaslardan kaçınanlarda yeterli sağlık okuryazarlık (hastallk önleme ve sağllğı geliștirme) düzeyi daha yüksektir $(p<0,05)$.

Sonuç Gebe kadınların yarıdan fazlası yeterli sağlık okuryazarlığı düzeyindedir. COVID-19 kurallarına uyumda yeterli sağlı okuryazarlı düzeyi yüksektir. Sağlık okuryazarlğı̆ın geliştirilmesi hem COVID-19 hastalı̆̆ hem de diğer sağlık sorunlarının çözümünde yarar sağlayabilir. 


\section{INTRODUCTION}

On the last day of 2019, pneumonia with unknown cause was reported in Wuhan, China's Hubei Province. In the first days of 2020, it was determined that pneumonia cases with an unknown cause were a new coronavirus that had not been detected in humans before. Coronavirus cases, which started to be seen in neighboring countries after China, spread rapidly and started to be seen in many countries. ${ }^{1}$ With the increase in the number of countries and cases with coronavirus, the World Health Organization (WHO) defined it as an "international public health emergency" on 30 January 2020 and a "global epidemic (pandemic)" on 11 March $2020 .^{2}$

Coronaviruses, which have different types, cause severe respiratory distress, starting from the common cold. The most known of these are; "Middle East Respiratory Syndrome Coronavirus (MERS)" and "Severe Acute Respiratory Syndrome (SARS)" which are viruses defined in previous years and which affected large masses. ${ }^{3}$ The coronavirus outbreak was initially named "SARS-CoV-2" due to its similarity to SARS and later named "Coronavirus Disease-2019 (COVID-19)".

COVID-19; has an average incubation period of 2-14 days. Although droplets mainly transmit COVID-19, it can also be transmitted by contacting of infected people with other individuals' hands and then taking the hands to the mouth, nose and eye mucosa. Although the infection's typical symptoms are respiratory symptoms such as fever, cough and dyspnea, uncommon symptoms such as head and sore throat, runny nose, muscle, joint pain, extreme weakness, loss of taste and smell, and diarrhea can also be seen. Although the disease can be asymptomatic, kidney failure, pneumonia, severe acute respiratory tract infection, and death may develop in extreme cases. ${ }^{5}$

Health literacy, which impacts the effective use of health information, can be defined as "the motivation, knowledge, and competence used to access, understand, evalu- ate and apply health information and make health-related decisions." Adequate health literacy enables the individual to make informed healthcare provision decisions, disease prevention, and health promotion issues. ${ }^{6}$ Inadequate health literacy is shown as less use of preventive health services, delay in seeking health care during periods of symptoms, failure to understand the individual's medical condition and adherence to medical instructions resulting in increased health care costs and increased mortality.-10

Pregnancy refers to an average of 280 days (40 weeks) from the first day of the last menstruation, starting with the union of the ovum and sperm. ${ }^{11,12}$ Although pregnancy is a natural event, it causes important anatomical, physiological and psychological changes in the organism of the pregnant woman. ${ }^{13}$ Pregnancy and pregnancy-related complications are considered among the major causes of morbidity and mortality among women of childbearing age, especially in developing countries. ${ }^{14}$ Risks that may occur with pregnancy are important not only for the health of the pregnant but also for the health of the fetus. Providing adequate and qualified prenatal care is one of the main things to be done for the health of both pregnant women and fetuses. Early diagnosis and treatment of health problems that may occur during pregnancy can be provided with antenatal care. Antenatal care, can reduce the mortality and morbidity that may occur and protect and improve the mother, fetus, and newborn's health. ${ }^{15,16}$ According to the "Antenatal Care Management Guideline" published by the Ministry of Health, a pregnant woman receives qualified antenatal care at least four times during pregnancy. According to the guideline, the first follow-up should be done before the 14th week of pregnancy, the second at 1824 weeks, the third at 24-28 weeks, and the fourth at 36-38 weeks. ${ }^{17}$ According to the 2018 Turkey Demographic and Health Survey (TDHS) data, 90.0\% of pregnant women received antenatal care at least four or more times. Antenatal care consists of urine and blood analysis, blood pressure measurement, ultrasound scanning, weight monitoring, iron supplements, tetanus vaccine, and the abdomen's ex- 
ternal palpation. ${ }^{18}$

Some physiological changes in the cardiorespiratory and immune systems during pregnancy make pregnant women more susceptible to infections. ${ }^{19}$ Due to influenza infection pregnant women applied to hospitals 6.8 times more than non-pregnant women and their need for intensive care was 6.5 times higher. ${ }^{20}$ Although there is no data that pregnant women have a higher risk of contracting COVID-19 infection, the risk of developing complications and morbidity has increased in pregnant women with sub-diseases. $^{21,22}$ Studies show that the preterm delivery and cesarean frequency are increased in cases who had COVID-19 during pregnancy. In a systematic review examining 790 cases with COVID-19 during pregnancy, the preterm delivery rate was $23 \%$ and the cesarean rate was $72 \% .{ }^{23}$ In another study involving 427 cases with COVID-19 during pregnancy, the preterm delivery rate was reported as $27 \%$ and cesarean rate as 59\%. ${ }^{24}$ Another problem for those who have had COVID-19 during pregnancy is the transmission of the virus from mother to the fetus or baby. Although vertical transition's extent and clinical significance are still unclear, possible vertical transition cases have been reported, especially in maternal infections in the last trimester. ${ }^{25}$ In a study in which nine pregnant women diagnosed with COVID-19 were followed-up, the presence of viruses was detected in two newborns. ${ }^{26}$

Women's and children's health are of great importance in the formation of healthy families and societies. The concept of being healthy for children depends on a healthy start to life from the antenatal period and a healthy growth and development process. Therefore, health literacy in women is vital in terms of both women's and children's health promotion and diseases prevention. ${ }^{27}$

This study was conducted to pregnant women's health literacy level and evaluate the relationship between the determined health literacy levels with COVID 19 knowledge, attitudes, and behaviors.

\section{MATERIAL and METHODS}

This cross-sectional and descriptive study was conducted on pregnant women who applied to the Gynecology and Obstetrics Outpatient Clinic of Erciyes University Hospitals between 15 September 2020 and 15 February 2021. For the study, approval from the Scientific Research Evaluation Commission of the Ministry of Health and the ethics committee approval (Decision No: 2020.32 on 12.10.2020) from the Scientific Research and Publication Ethics Committee of Cappadocia University was obtained. The study was carried out in accordance with the Helsinki Declaration Principles. Sample size in the study; “Turkey Health Literacy Survey," which according to the average general health literacy index were calculated based on the study results 30.4 (While this rate was 21.1 for the illiterate, this rate increased as the education increased to 33.8 for undergraduate graduates and 36.0 for master / doctorate graduates). Assuming that the average of the general health literacy index in pregnant women is similar (considering that it is from every education level) and could be 30.4; at 95\% confidence interval, alpha $=0.05$, power Beta $=0.80$, effect size $d=0.10$ were calculated as 357 pregnant women to be sampled.28 Four hundred fifty people were included in the study as there might be problems such as incomplete questionnaires. At the end of the study, the questionnaire forms of 381 pregnant women were evaluated. The reach rate is $84.7 \%$. Researchers prepared 12 questions about their socio-demographic characteristics and 13 questions related to their knowledge, attitude and behavior with COVID 19 for the pregnant women who applied to the Gynecology and Obstetrics Outpatient Clinic. In order to determine health literacy, a questionnaire form consisting of 32 questions, "Turkey Health Literacy Scale-32 (THLS-32)" was applied.29 Participants were informed about the subject and purpose of the study. An informed consent form was signed by all the participants before enrollment in the study. The questionnaire form consisted of face-to-face interview techniques following the pandemic rules (appropriate physical distance, etc.). 
THLS-32 consisted of two dimensions (Health treatment and service, Disease Prevention and Health Promotion) and four information processing processes (accessing health-related information, understanding health-related information, evaluating health-related information, and evaluating health-related information). Each of the 32 questions was scored between 1 and 4 ( 1 = very difficult, 2 = difficult, 3 = easy, 4 = very easy). Each question was based on the principle of evaluating how "easy" or "difficult" the specified behavior was, according to a person's own perception. As a result of the scale with the lowest " 0 points" and the highest " 50 points," the score range of 0-25 was defined as "inadequate," (> 25-33) the score range as "limited," (> 33-42) score range as "adequate" and (> 4250) as "excellent" health literacy.

In the evaluation of chi-square test, "inadequate, limited/ problematic, adequate, excellent" health literacy categories were re-categorized as adequate and inadequate health literacy. The data were evaluated with the SPSS 15.0 program. The Shapiro-Wilk test was used to evaluate whether the data were normally distributed. The mean and standard deviation was used for continuous data as descriptive statistics, whereas the number and percentage values were presented for categorical variables. The value of $\mathrm{p}<0.05$ was accepted as statistically significant.

\section{RESULTS}

Of the pregnant women, $23.9 \%$ has inadequate, $19.7 \%$ limited, $28.3 \%$ adequate and $28.1 \%$ had excellent general health literacy. The average general health literacy average was $33.28 \pm 12.63$. In the sub-dimensions, the highest level of adequate (adequate / excellent) health literacy was at the literacy of apply-use information relevant to health with $68.2 \%$. In the sub-dimensions, the lowest level of adequate (adequate /excellent) health literacy was at the literacy of Appraise/Judge/Evaluate information relevant to health with $50.1 \%$. (Table 1 ).

As the education level increased, the level of health literacy increased. While $47.1 \%$ of those with primary and lower education levels had adequate health literacy levels, this rate increased to $51.8 \%$ at the high school level and $74.5 \%$ for those with university education levels. The difference is statistically significant $(p=0.000)$. As the number of pregnancies increases, the level of health literacy decreases. Adequate health literacy level, $64.1 \%$ in those with one pregnancy, decreased from $57.3 \%$ in those with $2-3$ pregnancies to $46.2 \%$ in those with four or more pregnancies. The difference is statistically significant $(\mathrm{p}=0.040)$. Adequate health literacy levels are lower in those who use traditional contraceptive methods, those with chronic diseases, smokers, and those who consume alcohol. However, the differences are not statistically significant (Table 2).

Adequate health literacy level is higher in those who use masks and hand disinfectants, which are the most commonly used personal protective equipment. The level of adequate health literacy is higher in pregnant women who say their COVID-19 symptoms like fever, respiratory distress, and cough. The difference is statistically significant $(p=0.028 / 0.000 / 0.015)$. Pregnant women who think that COVID-19 is not transmitted through breast milk and complies with COVID-19 bans are higher in adequate health literacy. However, the differences were not statistically significant. Although the inadequate health literacy level is higher in those who think that COVID-19 creates an atmosphere of panic, the difference was not statistically significant (Table 3 ).

Pregnant women who respond that in case of continuous coughing / sneezing, cover the mouth and nose with a disposable tissue and avoid close contacts such as handshaking and hugging, have a higher level of adequate health literacy (Disease Prevention and Health Promotion Health Literacy). The difference is statistically significant $(\mathrm{p}=0.000$, Table 4$)$. 
Sakarya Med J 2021;11(3):533-541

DOĞAN et al., Health Literacy and COVID 19 in Pregnant Women

\begin{tabular}{|c|c|c|c|c|c|c|c|c|c|}
\hline \multirow[t]{2}{*}{ Health Literacy Indexes $(n=381)$} & \multicolumn{2}{|c|}{ Inadequate } & \multicolumn{2}{|c|}{$\begin{array}{l}\text { Problem- } \\
\text { atic }\end{array}$} & \multicolumn{2}{|c|}{ Adequate } & \multicolumn{2}{|c|}{ Excellent } & \multirow{2}{*}{$\begin{array}{l}\text { Average Health } \\
\text { Literacy Score }\end{array}$} \\
\hline & $\mathrm{n}$ & $\%$ & $\mathrm{n}$ & $\%$ & $\mathrm{n}$ & $\%$ & $\mathrm{n}$ & $\%$ & \\
\hline General Health Literacy & 91 & 23.9 & 75 & 19.7 & 108 & 28.3 & 107 & 28.1 & $33.28 \pm 12.63$ \\
\hline Health treatment and service Health Literacy & 75 & 19.7 & 73 & 19.2 & 126 & 33.1 & 107 & 28.1 & $33.64 \pm 12.46$ \\
\hline Disease Prevention and Health Promotion Health Literacy & 99 & 26.0 & 61 & 16.0 & 112 & 29.4 & 109 & 28.6 & $32.67 \pm 13.76$ \\
\hline Access/Obtain Information Relevant to Health & 100 & 26.2 & 43 & 11.3 & 128 & 33.6 & 110 & 28.9 & $33.17 \pm 13.38$ \\
\hline Understand Information Relevant to Health & 86 & 22.6 & 66 & 17.3 & 106 & 27.8 & 123 & 32.3 & $33.93 \pm 13.33$ \\
\hline Appraise/Judge/Evaluate Information Relevant to Health & 134 & 35.2 & 56 & 14.7 & 114 & 29.9 & 77 & 20.2 & $30.10 \pm 13.75$ \\
\hline Apply /Use Information Relevant to Health & 72 & 18.9 & 49 & 12.9 & 129 & 33.8 & 131 & 34.4 & $35.42 \pm 13.11$ \\
\hline
\end{tabular}

\begin{tabular}{|c|c|c|c|c|c|c|}
\hline \multirow{2}{*}{\multicolumn{2}{|c|}{ Characteristic }} & \multirow{3}{*}{$\begin{array}{c}\text { Total } \\
117\end{array}$} & \multicolumn{2}{|c|}{ Adequate HL $(n=215)$} & \multirow{2}{*}{$\mathrm{X}^{2}$} & \multirow{2}{*}{$\mathbf{p}$} \\
\hline & & & $\mathbf{n}$ & $\%$ & & \\
\hline \multirow{3}{*}{ Age Group (Years) } & 25 and under & & 73 & 62.4 & \multirow{3}{*}{2.750} & \multirow{3}{*}{0.253} \\
\hline & $26-35$ & 220 & 120 & 54.5 & & \\
\hline & 35 and over & 44 & 22 & 50.0 & & \\
\hline \multirow{3}{*}{ Education } & Primary school and lower & 157 & 74 & 47.1 & \multirow{3}{*}{21.214} & \multirow{3}{*}{0.000} \\
\hline & High school & 114 & 59 & 51.8 & & \\
\hline & University degree & 110 & 82 & 74.5 & & \\
\hline \multirow{2}{*}{ Occupation } & Working & 85 & 57 & 67.1 & \multirow{2}{*}{5.027} & \multirow{2}{*}{0.025} \\
\hline & Not Working (housewife) & 296 & 158 & 53.4 & & \\
\hline \multirow{2}{*}{ Spouse's occupation } & Health professional & 16 & 10 & 62.5 & \multirow{2}{*}{0.250} & \multirow{2}{*}{0.617} \\
\hline & Non-Health professional & 365 & 205 & 56.2 & & \\
\hline \multirow{3}{*}{ Number of pregnancies } & 1 & 103 & 66 & 64.1 & \multirow{3}{*}{6.437} & \multirow{3}{*}{0.040} \\
\hline & $2-3$ & 185 & 106 & 57.3 & & \\
\hline & 4 and over & 93 & 43 & 46.2 & & \\
\hline \multirow{2}{*}{ Lower pregnancy } & Yes & 124 & 59 & 47.6 & \multirow{2}{*}{5.856} & \multirow{2}{*}{0.016} \\
\hline & No & 257 & 156 & 60.7 & & \\
\hline \multirow{2}{*}{ Contraceptive methods $(n=178)$} & Modern & 132 & 78 & 59.1 & \multirow{2}{*}{0.667} & \multirow{2}{*}{0.414} \\
\hline & Traditional & 46 & 24 & 52.2 & & \\
\hline \multirow{2}{*}{ Chronic disease } & Yes & 92 & 48 & 52.2 & \multirow{2}{*}{0.894} & \multirow{2}{*}{0.344} \\
\hline & No & 289 & 167 & 57.8 & & \\
\hline \multirow{2}{*}{ Smoking } & Yes & 60 & 33 & 55.0 & \multirow{2}{*}{0.059} & \multirow{2}{*}{0.808} \\
\hline & No & 321 & 182 & 56.7 & & \\
\hline \multirow{2}{*}{ Alcohol drinking } & Yes & 6 & 3 & 50.0 & 0102 & - 78 \\
\hline & No & 375 & 212 & 56.5 & & 0.147 \\
\hline
\end{tabular}


Sakarya Med J 2021;11(3):533-541

DOĞAN et al., Health Literacy and COVID 19 in Pregnant Women

\begin{tabular}{|c|c|c|c|c|c|c|c|}
\hline \multicolumn{2}{|l|}{ COVID-19 Knowledge, Attitudes and Behavior } & \multicolumn{2}{|c|}{$\begin{array}{c}\text { Inadequate HL } \\
(n=166)\end{array}$} & \multicolumn{2}{|c|}{$\begin{array}{l}\text { Adequate HL } \\
\quad(n=215)\end{array}$} & \multirow{2}{*}{$\begin{array}{c}\mathrm{X}^{2} \\
1.263 \\
\end{array}$} & \multirow{2}{*}{$\begin{array}{c}\mathbf{p} \\
0.261\end{array}$} \\
\hline The met freount nersol nrotective & Mask & $\begin{array}{c}\mathrm{n} \\
150\end{array}$ & $\begin{array}{c}\% \\
90.4\end{array}$ & $\frac{n}{201}$ & $\begin{array}{c}\% \\
93.5 \\
\end{array}$ & & \\
\hline The most irequent personar protective & Hand disinfectants & 51 & 30.7 & 73 & 34.0 & 0.445 & 0.505 \\
\hline \multirow{3}{*}{ The most common symptom of COVID-19* } & Fever & 102 & 61.4 & 155 & 72.1 & 4.837 & 0.028 \\
\hline & Respiratory distress & 83 & 50.0 & 146 & 67.9 & 12.527 & 0.000 \\
\hline & Cough & 78 & 47.0 & 128 & 59.8 & 5.938 & 0.015 \\
\hline \multirow{2}{*}{ COVID-19 transmission * } & Close Contact & 119 & 71.7 & 159 & 74.0 & 0.244 & 0.621 \\
\hline & Respiratory & 51 & 30.7 & 88 & 40.9 & 4.212 & 0.040 \\
\hline Frequency to follow the COVID-19 process & Always & 75 & 45.2 & 108 & 50.2 & 2.072 & 0,722 \\
\hline \multirow{2}{*}{ Source to follow the COVID- 19 process } & TV/Radio & 122 & 73.5 & 167 & 77.7 & 0.894 & 0.344 \\
\hline & Internet & 71 & 42.8 & 115 & 53.5 & 4.306 & 0.038 \\
\hline Complying with COVID-19 bans & Yes & 155 & 93.4 & 208 & 96.7 & 2.364 & 0.124 \\
\hline COVID-19 caused panic & Yes & 99 & 59.6 & 111 & 51.6 & 2.430 & 0.119 \\
\hline COVID-19 positive in the family & Yes & 98 & 59.0 & 147 & 68.4 & 3.557 & 0.059 \\
\hline $\begin{array}{l}\text { COVID-19 is not transmitted through breast } \\
\text { milk }\end{array}$ & Yes & 118 & 71.1 & 159 & 74.0 & 0.389 & 0.533 \\
\hline
\end{tabular}

\begin{tabular}{|c|c|c|c|c|c|c|}
\hline \multirow[t]{2}{*}{ COVID-19 Knowledge, Attitudes and Behavior } & \multicolumn{2}{|c|}{$\begin{array}{l}\text { Inadequate HL } \\
\quad(\mathbf{n}=160)\end{array}$} & \multicolumn{2}{|c|}{$\begin{array}{l}\text { Adequate HL } \\
\quad(\mathbf{n}=221)\end{array}$} & \multirow[t]{2}{*}{$\mathrm{X}^{2}$} & \multirow{2}{*}{$\mathbf{p}$} \\
\hline & $\mathrm{n}$ & $\%$ & $\mathrm{n}$ & $\%$ & & \\
\hline Wash your hands frequently with soap and water for at least 20 seconds & 150 & 93.8 & 214 & 96.8 & 2.083 & 0.353 \\
\hline $\begin{array}{l}\text { Cover the mouth and nose with disposable wipes during coughing or } \\
\text { sneezing. If there is no wipe, use the inside of the elbow. }\end{array}$ & 136 & 85.0 & 216 & 97.7 & 22.539 & 0.000 \\
\hline Keep at least 3-4 steps away from people who show signs of a cold. & 146 & 91.3 & 211 & 95.5 & 2.814 & 0.245 \\
\hline Ventilate the rooms every day. & 150 & 93.8 & 216 & 97.7 & 7.323 & 0.026 \\
\hline Avoid close contacts such as handshaking or hugging. & 143 & 89.4 & 211 & 95.5 & 8.271 & 0.016 \\
\hline Do not touch your eyes, mouth, and nose with your hands. & 127 & 79.4 & 202 & 91.4 & 11.963 & 0.003 \\
\hline Do not share your personal belongings such as towels. & 137 & 85.6 & 199 & 90.0 & 2.909 & 0.234 \\
\hline Do not take goods and food into the house without wiping-washing. & 122 & 76.3 & 176 & 79.6 & 4.483 & 0.106 \\
\hline Pay attention to drink plenty of fluids. & 140 & 87.5 & 202 & 91.4 & 2.058 & 0.357 \\
\hline Pay attention to balanced nutrition. & 136 & 85.0 & 201 & 91.0 & 3.375 & 0.185 \\
\hline Pay attention to sleep patterns. & 120 & 75.0 & 172 & 77.8 & 0.797 & 0.671 \\
\hline
\end{tabular}




\section{DISCUSSION}

In a study conducted in 2014, 26.2\% of teachers (Male $18.4 \%$ / Female 41.7\%), in a study conducted in 2016, $28.8 \%$ of academicians (Male 27.6\% / Female 31.5\%) and in a study conducted in 2016, it was found that $30.6 \%$ of the participants (Male 28.8\% / Female 32.5\%) had adequate (adequate / excellent) health literacy.29-31 Also, in national and international studies, it has been found that as the education level increases, the level of health literacy also increases. ${ }^{32-34}$ In a study conducted in Erzurum in 2017, 54.9\% of pregnant women were found to have adequate (adequate /excellent) health literacy. ${ }^{35}$ In our study, a total of $56.4 \%$ of pregnant women, $23.9 \%$ of whom were inadequate, $19.7 \%$ were limited, $28.3 \%$ were adequate and $28.1 \%$ were at an excellent level, in total, $56.4 \%$ were at the level of adequate health literacy and as the education level increased, the level of adequate health literacy increased (Tables 1 and 2). The health literacy level of pregnant women is higher than the studies conducted in both private groups. The general society may be due to the importance of health literacy in recent years and the positive and synergy effect of higher education on women's health.

It is reported that the level of health literacy also affects women's knowledge about contraception and family planning. ${ }^{36}$ In a study, it was found that women with high levels of health literacy have higher knowledge about contraception methods and the days when pregnancy may be at risk in the monthly cycle. ${ }^{37}$ In another study, unplanned pregnancies were higher in women with low health literacy levels.38 In our study, there is an inverse relationship between the number of pregnancies and the level of health literacy. Adequate health literacy decreases as the number of pregnancies increases. While $64.1 \%$ of the pregnant women with one pregnancy are at the adequate health literacy level, the adequate health literacy level is $46.2 \%$ in pregnant women with a pregnancy number of four and above $(\mathrm{p}=0.040)$. Similarly, while pregnant women's adequate health literacy level with an abortion is $47.6 \%$, this rate is $60.7 \%$ in pregnant women without abortion $(\mathrm{p}=0.016)$.
Adequate health literacy level is high among those using modern methods of contraception (Table 2).

One of the factors influenced by the level of health literacy recognizing the person's health problems, applying to the health institution at the right time, and complying with the treatment and follow-up. The most common clinical symptoms and signs in COVID-19 are fever $\left(37.8\right.$ or $\left.38^{\circ} \mathrm{C}\right)$ $(88 \%)$ and dry cough (68\%). It has been found that more than $80 \%$ of hospitalized patients have one of these two symptoms..$^{20}$ In our study, adequate health literacy level was higher in pregnant women who said that cough, respiratory distress and fever are common symptoms of COVID-19 ( $\mathrm{p}=0.028 / 0.000 / 0.015$, Table 3 ). Knowing the symptoms of COVID-19 for pregnant women will enable early applications to healthcare institutions. Early application to healthcare institutions can have positive results in terms of the course of the COVID-19 disease.

As the rate of understanding and using the necessary information individuals' health increases, the behaviors of preventing diseases and providing early diagnosis of diseases increase. ${ }^{36}$ In our study, the highest sub-dimension of the health literacy index was "Apply /Use Information Relevant to Health" with $68.2 \%$ and "Understand Information Relevant to Health" with $60.1 \%$ (Table 1). Pregnant women were found to comply with the COVID-19 rules at a rate of 76.4- 96.1\% (Table 4). In all COVID-19 rules, adequate health literacy (disease prevention and health promotion) levels are high. The differences between them were found to be statistically significant in those who said that they avoided close contacts such as handshaking and hugs, that they ventilate the rooms every day, and that they cover the mouth and nose in the case of coughing/sneezing, or the inside of the elbow (Table 4).

The fact that the study was conducted only in a public (university) hospital is a limitation of the study. For this reason, its results cannot be generalized to the whole population. 


\section{CONCLUSION}

Adequate health literacy level is high in pregnant women. Adequate health literacy level is higher in pregnant women who identify fever, respiratory distress and cough as the symptoms of COVID-19. With all COVID-19 rules, adequate health literacy levels are high. Health literacy levels of pregnant women in accessing and evaluating health-related information are lower. The number of studies that improve pregnant women's health literacy and enable them to access and evaluate health information should be increased. Improving health literacy in pregnant women can benefit from solving problems related not only to COVID-19 disease but also to other health conditions. Thus, it can have a positive effect on the health of both pregnant women and their children.

Ethics approval for this study was obtained from Scientific Research and Publication Ethics Committee of Cappadocia University (Decision No: 2020.32 on

12.10.2020) 
Sakarya Med J 2021;11(3):533-541

DOĞAN et al., Health Literacy and COVID 19 in Pregnant Women

\section{References}

1. Guan W, Ni Z, Hu Y, Liang W, Ou C, He J, et al. Clinical Characteristics of Coronavirus Disease 2019 in China. New England Journal of Medicine 2020 February 28. doi: 10.1056/ NEJMoa2002032

2. Doğan M, Bayraktar M. COVID-19 with a Public Health Perspective: Measures Taken in Turkey and Public Compliance with the Measures. Iran J Public Health 2020;49, (Suppl.1): $67-75$.

3. McIntosh K. Coronavirus disease 2019 (COVID-19). In: UpToDate Hirsch CH, Bloom H(ed), UpToDate 2020

4. World Health Organization (WHO). (2020, September 20). Coronavirus disease (COVID-19) Situation reports. https://www.who.int/emergencies/diseases/novel-coronavirus-2019/situation-reports (Erișim Tarihi: 15.02.2021)

5. T.C. Sağlı Bakanlı̆̆ı Bilimsel Danışma Kurulu Çalıșması, COVID-19 (SARS-CoV-2 Enfeksiyonu) Genel Bilgiler, Epidemiyoloji ve Tani, 7 Aralk 2020. https://covid19.saglik.gov. tr/Eklenti/39551/0/covid-19rehberigenelbilgilerepidemiyolojivetanipdf.pdf (Erişim Tarihi: 15.02.2021)

6. Sorensen K, Van den Broucke S, Fullam J, Doyle G, Pelikan J, Slonska Zet, al. Health literacy and public health: A systematic review and integration of definitions and models. BMC Public Health 2012; 12(80): 1-13. doi:10.1186/1471-2458-12-80

7. Doğan M, Çetinkaya F. Akademisyenlerde Sağlık Okuryazarlı̆ı Düzeyinin Olumlu Să̆lık Davranışlarıyla İlişkisi, Sağllk Bilimleri Dergisi (Journal of Health Sciences) 2019; 28(3);135,141. DOİ: https://doi.org/10.34108/eujhs.492647.

8. Dewalt DA, Berkman ND, Sheridan S, Lohr KN, Pignone MP. Literacy and Health Outcomes. Journal of General Internal Medicine 2004;19:1228-1239. https://doi.org/10.1111/ j.1525-1497.2004.40153.x

9. Mancuso JM. Health Literacy: A Concept/Dimensional Analysis. Nursing \& Health Sciences 2008;10:248-255. DOI: 10.1111/j.1442-2018.2008.00394.x

10. Tokuda Y, Doba N, Butler JP, Paasche-Orlow MK. Health Literacy and Physical and Psychological Wellbeing in Japanese Adults. Patient Education and Counselling 2009;75: 411-417. DOI: 10.1016/j.pec.2009.03.031

11. Taşkın L. Doğum ve Kadın Sağlı̆̆ı Hemşireliği. (Genişletilmiş 13. Baskı) Ankara: Akademisyen Tip Kitabevi, 2015.

12. Arslan Özkan H, Bilgin Z. Kantta Dayalı Gebelik ve Doğum Yönetimi. Ankara: Ankara Nobel Tip Kitapevleri, 2019.

13. Taşkın L. Gebeliğin Psikososyal ve Kültürel Boyutları. İçinde: Taşkın L, Eds. Doğum ve Kadın Sağlığı Hemşireliği. Ankara: Sistem Ofset Matbaactlı;; 2012; 215-20.

14. Aygar H, Metintaş S. Bir Kalkınma Göstergesi Olarak Anne Ölümleri. ESTÜDAM Halk Sağlı̆̆t Dergisi 2018;3(3):63-70.

15. Kaya F, Serin Ö. Doğum öncesi bakımın niteliği. TJOD Dergisi 2008;5(1):28-35.

16. Pirinçci E, Polat A, Köroğlu A, Kumru S. Bir üniversite hastanesinde doğum yapan kadınların doğum öncesi bakım alma durumu ve etkileyen faktörler. ADÜ Tip Fakültesi Dergisi 2010;11(2):1-7.

17. Doğum Öncesi Bakım Yönetim Rehberi, Yayın No: 925. Ankara: T.C. Sağlık Bakanlı̆̆ı Türkiye Halk Sağllğı Kurumu Kadın ve Üreme Sağlığı Daire Bașkanlığı, 2018. https://khgmsaglikhizmetleridb.saglik.gov.tr/Eklenti/28085/0/dogumoncesibakimyonetimrehberipdf.pdf

18. TNSA, 2018. Hacettepe Unniversitesi Nüfus Etütleri Enstitüsü. (2019). 2018 Türkiye Nüfus ve Sağlık Araștırması. Hacettepe Üniversitesi Nüfus Etütleri Enstitüsü, T.C. Cumhurbașkanlğ̆ Strateji ve Bütçe Başkanlığı ve TÜBİTAK, Ankara, Türkiye. http://www.hips.hacettepe.edu.tr/tnsa2018/rapor/TNSA2018_ana_Rapor.pdf

19. Liang H, Acharya G. Novel corona virus disease (COVID-19) in pregnancy: What clinical recommendations to follow? Acta obstetricia et gynecologica Scandinavica 2020; 99(4), 439442. https://doi.org/10.1111/aogs.13836

20. T.C. Sağlık Bakanlığı Bilimsel Danışma Kurulu Çalışması, COVID-19 (SARS-CoV-2 Enfeksiyonu) Solunum Sistemi Hastalıklarının Yaygın Olduğu Dönemde Sağlık Kurulușlarında Gebe Takibi.
21. CDC Centers for Disease Control and Prevention. Coronavirus Disease 2019 (COVID-19). Available from: https://www.cdc.gov/coronavirus/2019-ncov/hcp/inpatient-obstetric-healthcare-guidance.html (cited 2020 March 26).

22. Ellington S, Strid P, Tong VT, Woodworth K, Galang RR, Zambrano LD, et al. Characteristics of Women of Reproductive Age with Laboratory-Confirmed SARS-CoV-2 Infection by Pregnancy Status- United States, January 22-June 7, 2020. MMWR Morb Mortal Wkly Rep 2020; 69:769-75.

23. Dubey P, Reddy SY, Manuel S, Dwivedi AK. Maternal and neonatal characteristics and outcomes among COVID-19 infected women: An updated systematic review and meta-analysis. Eur J Obstet Gynecol Reprod Biol 2020; 252:490-501. doi: 10.1016/.j.jogrb.2020.07.034

24. Knight M, Bunch K, Vousden N, Morris E, Simpson N, Gale C, et al. Characteristics and outcomes of pregnant women admitted to hospital with confirmed SARS-CoV-2 infection in UK: national population-based cohort study. BMJ 2020; 369:m2107. doi: 10.1136/bmj. $m 2107$.

25. Kotlyar A, Grechukhina O, Chen A, Popkhadze S, Grimshaw A, Tal O, et al. Vertical Transmission of COVID-19: A Systematic Review and Meta-analysis. Am J Obstet Gynecol 2020 S0002-9378(20)30823-1. https://doi.org/10.1016/j.ajog.2020.07.049

26. Chen H, Guo J, Wang C, Luo F, Yu X, Zhang W, et al. Clinical characteristics and intrauterine vertical transmission potential of COVID-19 infection in nine pregnant women: a retrospective review of medical records. The Lancet 2020; 395(10226): 809-15. DOI:https:/ doi.org/10.1016/S0140-6736(20)30360-3

27. Gönenç İM. Kadın Sağllğı Açısından Sağllk Okuryazarlı̆̆ı, Yildırım F, Keser A, (Editörler). Sağlık Okuryazarlı̆̆ı, 1. Baskl. Ankara: Ankara Üniversitesi Basımevi; 2015. s:61-73.

28. Yazıcıoğlu Y, Erdoğan S. SPSS Uygulamalı Bilimsel Araștırma Yöntemleri, 2. Baskı. Ankara: Detay Yayincilik, 2004.

29. Okyay P, Abactgil F. Türkiye Sağllk Okuryazarlı̆̆ı Ölçekleri Güvenilirlikve Geçerlilik Çalışması, 1. Baskı. Ankara: Sağlık Bakanlı̆̆ı, 2016.

30. Yilmazel G, Çetinkaya F. Health literacy among schoolteachers in Çorum, Turkey, EMHJ 2015; 21(8): 598-605

31. Doğan M, Çetinkaya F. (2019). The Level of Health Literacy of Academicians and Factors Affecting It, Hacettepe Journal of Health Administration 2019,22(2): 389-400.

32. Dadipoor S, Ramezankhani A, Alavi A, Aghamolaei T, Safari-Moradabadi A. Pregnant women's health literacy in the South of Iran, Journal of Family \& Reproductive Health 2017;11(4): 211-218.

33. Kaya Șenol D, Göl I, Aydın Özkan S. The effect of health literacy levels of pregnant women on receiving prenatal care: a cross-sectional descriptive study, International Journal of Caring Sciences 2019;12(3):1717-1724.

34. Orkan O, Torsten Michael B, Eva-Maria B, Klaus H, Ullrich B, Doris S. Coronavirus-Related Health Literacy: A Cross-Sectional Study in Adults during the COVID-19 Infodemic in Germany, Int. J. Environ. Res. Public Health 2020;17, 5503; doi:10.3390/ijerph17155503.

35. Yllmaz S, Kavuncuoğlu D, Koşan Z, Göktuğ Kadıoğlu B. Erzurum İl Merkezinde Hastanelere Başvuran Gebelerin Sağlık Okuryazarlğı̆ Düzeyi ve Etkili Faktörler, 3. Uluslararası 21. Ulusal Halk Sağhlğı Kongresi, 2020; 915-916.

36. Shieh C, Halstead JA. Understanding the impact of health literacy on women's health. Journal of Obstetric, Gynecologic, \& Neonatal Nursing 2009;38, 601-612.

37. Gazmararian JA, Parker RM, Bake DW. Reading skills and family planning knowledge and practices in a low-income managed-care population. Obstetrics and Gynecology 1999;93(2), 239-244.

38. Endres LK, Sharp LK, Haney E, Dooley SL. Health literacy and pregnancy preparedness in pregestational diabetes. Diabetes Care 2004;27(2), 331- 334 